\title{
Effect of Irrigation Waters in Different Salinity Levels on Crop Yield and Energy Use in Greenhouse Tomato Production in Turkey: A Case Study in Kırklareli Province
}

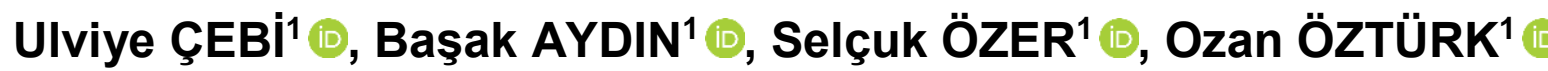

${ }^{1}$ Atatürk Soil and Water Agricultural Meteorology Research Institute, 39060, Kırklareli / Turkey

\section{Article History}

Received 17 August 2020

Accepted 05 October 2020

First Online 15 October 2020

\section{Corresponding Author}

E-mail: ulviyecebi@yahoo.com

\section{Keywords}

Energy use efficiency

Greenhouse

Irrigation

Salinity

Tomato

\begin{abstract}
This study was carried out in a quonset type plastic covered unheated greenhouse on the lands of Atatürk Soil Water and Agricultural Meteorology Institute in Kırklareli, Turkey. In the study, the effect of different salinity and irrigation water levels which were applied to tomato plant, irrigated by drip irrigation in greenhouse, on yield and energy use efficiency was evaluated and the optimum irrigation application was determined. In the study, 'Swanson F1' type tomato was grown as plant material. The trial was carried out on 36 plots with three replications according to split plots experimental design and four different irrigation water salinity levels were on main plots and three irrigation levels were on sub plots. The best result was obtained from $T_{1} S_{2}$ subject in terms of yield and energy use efficiency. The average yield was determined as $109060 \mathrm{~kg} \mathrm{ha}^{-1}$ and energy output/input ratio, energy productivity and specific energy were found as $1.51,1.89 \mathrm{~kg} \mathrm{MJ}^{-1}$ and $0.53 \mathrm{MJ} \mathrm{kg}^{-1}$ in $\mathrm{T}_{1} \mathrm{~S}_{2}$ subject, respectively. It was concluded that the optimum method should be on low salinity level and the irrigation water application should be on the level in order to bring the current moisture level to the field capacity.
\end{abstract}

\section{Introduction}

Irrigated farming has an important role in the compensation of food requirement of rapidly increasing World population besides modern agriculture techniques. Nevertheless, domestic and industrial purposeful water usage gradually increases with the increase of population and industry and a great competition occurs with the agricultural purposeful water usage (UI, 2007). On the other hand, supply of qualified irrigation water from nature becomes difficult day by day against the deterioration of the water in terms of qualification and quantity, environment pollution and climate changes (Atay, 2006). Nowadays, the quality of the irrigation water constitutes a significant problem as the provision of the adequate water. Considering the decrease of the water against the uncontrolled increase of the world population and the water share problem, the usage of low quality waters in the agricultural irrigation will be an essential requirement in the compensation of the increasing requirement.

Considering that the agricultural areas are restricted and the food requirement increases in the world, productive usage of the current areas becomes obligatory. Providing the sufficient irrigation water in the agricultural areas becomes difficult day by day. Especially in the arid and semiarid regions, decrease and pollution of the natural sources for irrigated farming, being obliged to make irrigation with low qualified irrigation water generally cause the salinization of the agricultural areas. Irrigation water and soil salinity effect the development of the plants negatively and reduces the quality of the crop significantly. Researches are conducted in order to make harmless farming in the soil and the plant by using saline water in the world. 
All the cultivated plants are sensitive against salinity at a certain level. A continuous decrease in the yield occurs by the increase of the salinity. Especially in the vegetables, determination of the changes in plant characteristics, yield and quality and the salinity in the agricultural areas is quite significant in case of the usage of the low quality waters.

Tomato which is a fibroid and lycopene rich plant and a quite delicious vegetable, has an important role in our country economy due to the diversely consumption and processing. It is one of the significant income sources of the farmers in the cultivated regions. In Turkey, the most produced and consumed crop is tomato in raw vegetable production. Tomato is grown in a wide range of climate zone and it is not a selective plant in terms of soil requests. It shows an intermediate precision against soil salinity and the fruit yield decreases when the electrical conductivity is over $2.5 \mathrm{dS} \mathrm{m}^{-1}$ (Tülücü, 2003). Tomato plant can be used as a model plant in the improvement of the saline areas and the usage of the bad qualified waters due to the rich information existence about its physiology and genetics (Cuartero and Fernandez-Munoz, 1999).

Greenhouse farming enables the marginal evaluation of the small areas by providing the obtainment of high amounts of yields from unit area and besides it is one of the most significant agricultural activities due to the regular labor usage in Turkey (Sevgican et al., 1990). Greenhouse farming increases rapidly as it is obtained more income when compared with open field farming.

Greenhouse farming is a new agricultural activity in Thrace Region and it rapidly increases due to the big consumption center, İstanbul, in the region. On the other hand, the limited water sources and the threatening of these sources in terms of quality and quantity by the rapidly and unplanned developing industry, restrict the amount and quality of the waters. It was observed that the quality of the waters decreased and the salt ratios increased of in the region.

Tomato, cucumber, pepper and eggplant farming are done in the ratios of $51 \%, 20.2 \%, 17.3 \%$ and $8.6 \%$, respectively in greenhouse conditions in Turkey. In the remaining area with the ratio of $2.9 \%$, the vegetable kinds such as melon, bean and squash are grown (Anonymous, 2018a). In Turkey, 5.9 million tons of vegetables constitute the total of 6.1 million tons of greenhouse production. Total greenhouse existence is 59900 ha and 31700 ha $(53 \%)$ of this is composed of high systems. Turkey takes place in the first four countries in the world and is placed on the top with Spain in Europe in terms of greenhouse existence. In the last ten years, greenhouse land size reached to 0.4 ha from 0.2 ha in Turkey (Anonymous, 2018b). According to 2018 year data of Turkish Statistical Institute, total of 3888555 tons of tomato production occurred in 28081 ha area in Turkey and total of 5838 tons of tomato production occurred in 13.8 ha area in Thrace Region.

Energy use efficiency continuously decreases in spite of the increase of the energy consumption in order to increase the productivity in the agriculture in Turkey. Further to that, efficient energy usage is required in order to conduct a sustainable farming, decrease the air pollution, decrease the usage of the fossil fuels and provide the economic achievements. For this reason, the researchers concentrated on the energy analysis on different agricultural production areas for the planning of the sources in the ecosystem (Ekinci et al., 2005). Several studies were conducted in order to determine the energy use efficiency in vegetable production and evaluate the environmental effects in open field and greenhouse conditions, such as tomato (Hatılı ıt al., 2006; Çetin and Vardar, 2008; Pashaee et al., 2008; Mihov and Tringovska, 2010; Rezvani Moghaddam et al., 2011; Jadidi et al., 2012; Bilalis et al., 2013; Sepat et al., 2013; Taki et al., 2013; Sabaghi and Masihi, 2014; Dimitrijević et al., 2015; Mirasi et al., 2015), tomato, cucumber, pepper, eggplant (Özkan et al., 2004; Çanakçı and Akıncı, 2006), lettuce, clover and broad bean (Razavinia et al., 2015), tomato and cucumber (Taki et al., 2012), basil (Pahlavan et al., 2012), cucumber (Mohammadi and Omid, 2010; Monjezi et al., 2011; Pahlavan et al., 2011; Darijani et al., 2012; Yousefi et al., 2012; Sami and Reyhani, 2015), onion, tomato, sweet pepper, hot pepper (İbrahim, 2011), potato (Mohammadi et al., 2008), tomato, melon, water melon (Çanakçı et al., 2005), lettuce (Dimitrijević et al., 2010), tomato, pepper and lettuce (Kuswardhani et al., 2013), water melon and melon (Baran and Gökdoğan, 2014).

In this study, the effects of irrigation waters in different irrigation levels of tomato crop irrigated by drip irrigation under greenhouse conditions in Kırklareli province on crop yield and energy use were evaluated and the optimal irrigation application was determined.

\section{Material and Method}

\subsection{Material}

The study was carried out between 2014 and 2016 in the quonset type plastic covered unheated greenhouse which had an area of $608 \mathrm{~m}^{2}$ $(76 \mathrm{~m} \times 8 \mathrm{~m})$ on the lands of Atatürk Soil Water and Agricultural Meteorology Research Institute located $4 \mathrm{~km}$ west of Kırklareli province. Kırklareli province is located within $41^{\circ} 42^{\prime}$ North latitude and $27^{\circ} 14^{\prime}$ east longitude and total surface area of the province is 655036 ha.

In the study, "Swanson F1" variety of tomato (Lycopersicon esculentum) was used as the plant material. The fruits of Swanson F1 tomato variety's shelf life is long. It is an appropriate variety for open 
field tomato farming and greenhouse farming in Thrace Regions. The fruits of this variety are round and $180-190 \mathrm{~g}$.

\subsection{Method}

The experiment was carried out according to split plot design with three replications. The four different irrigation salinities ( $\mathrm{T}_{1}$ : Dam water, ECw: $0.38 \mathrm{dS} \mathrm{m}^{-1}, \mathrm{~T}_{2}$ : Well water, ECw: $1.1 \mathrm{dS} \mathrm{m}^{-1}, \mathrm{~T}_{3}$ : ECw: $2.5 \mathrm{dS} \mathrm{m}^{-1}$, and T4: ECw: $5.0 \mathrm{dS} \mathrm{m}^{-1}$ ) were the main plots and the three irrigation levels $\left(S_{1}\right.$ : Irrigation water application on the level of $70 \%$ of the field capacity on the current moisture level in the profile, $\mathrm{S}_{2}$ : Irrigation water application on the level of bringing the current moisture in the profile to the field capacity, and $\mathrm{S}_{3}$ : Irrigation water application more than $30 \%$ of the field capacity on the current moisture level in the profile)were the sub plots of the experiment and the experiment was carried out in total of 36 plots for three years. The planting of the tomato plant was done as $0.8 \mathrm{~m}$ inter-row and 0.5 $\mathrm{m}$ intra-row (Planting: $3.2 \times 3.0=9.6 \mathrm{~m}^{2}$, Harvesting: $2.0 \times 1.6=3.2 \mathrm{~m}^{2}$ ). Between the plots, there was a $1 \mathrm{~m}$ of interspace.

The irrigation water used in the experiment was obtained from the deep well within the institute land borders and Kırklareli Dam. The $T_{3}$ and $T_{4}$ subjects, which were created as artificial, were created by adding in different ratios of salts in 5 tons of tanks. Some chemical characteristics of the irrigation waters and the irrigation water classes are given in Table 1. The salts which were used in order to create the $T_{3}$ and $T_{4}$ subjects and the amounts are given in Table 2.

The amounts of the inputs used in tomato production (human labor, machinery, diesel, pesticides, fertilizers, electricity, irrigation water, seed and farmyard manure) and the output (yield) were calculated per hectare in order to calculate the energy equivalents. Then, these values were multiplied by the energy equivalent coefficients (Table 3). Energy equivalents of the inputs and outputs for greenhouse tomato production were obtained from the previous studies. Energy equivalents of the inputs and the outputs were expressed in mega joule (MJ). The calculations were done according to the averages of three years data for all the main and the sub plots.

Following the calculation of energy input and output equivalents, the energy use efficiency, energy productivity, specific energy and net energy were calculated according to the following formulas (Mandal et al., 2002).

Energy use efficiency $=\frac{\text { Energy output }\left(\mathrm{MJ} \mathrm{ha}^{-1}\right)}{\text { Energy input }\left(\mathrm{MJ} \mathrm{ha}^{-1}\right)}$

Energy productivity $=\frac{\text { Tomato production }\left(\mathrm{kg} \mathrm{ha}^{-1}\right)}{\text { Energy input }\left(\mathrm{MJ} \mathrm{ha}^{-1}\right)}$

Specific energy $=\frac{\text { Energy input }\left(\mathrm{MJ} \mathrm{ha} \mathrm{h}^{-1}\right)}{\text { Tomato production }\left(\mathrm{kg} \mathrm{ha}^{-1}\right)}$

Net energy=Energy output - Energy input

The energy inputs were examined in direct, indirect, renewable and non-renewable forms. The direct energy includes human labor, diesel fuel, irrigation water and electricity. The indirect energy consists of pesticides, fertilizers, farmyard manure, seed and machinery. On the other hand, renewable energy includes human labor, farmyard manure, seed and irrigation water whereas non-renewable energy consists of diesel fuel, fertilizers, pesticides, machinery and electricity (Yılmaz et al., 2010).

The data of the tomato yield were subjected to variance analysis and evaluated. The statistical evaluations were done by using JMP package program. The evaluations were done on 0.01 and 0.05 significance levels and the significant subjects were subjected to LSD test.

\section{Results and Discussion}

\subsection{Yield}

Ten harvestings were done between 12 July and 16 September in 2014 which was the first year of the research, 10 harvestings were done between 9 July and 9 September in the second year and 9 harvestings were done between 1 July and 29 August in the third year. The yield values are given

Table 1. Characteristics of the irrigation waters

\begin{tabular}{|c|c|c|c|c|c|c|c|c|}
\hline & $\mathrm{pH}$ & $\begin{array}{c}E C \\
\left(\mathrm{dS} \mathrm{m}^{-1}\right)\end{array}$ & $\mathrm{Na}$ & $\mathrm{K}$ & $\frac{\mathrm{Ca}+\mathrm{Mg}}{\mathrm{meL}^{-1}}$ & $\mathrm{Cl}$ & $\mathrm{SO}_{4}$ & Irrigation water class* \\
\hline $\mathrm{T}_{1}$ & 7.58 & 0.38 & 0.45 & 0.07 & 2.94 & 0.25 & 0.23 & $\mathrm{C}_{2} \mathrm{~S}_{1}$ \\
\hline $\mathrm{T}_{2}$ & 7.30 & 1.10 & 2.25 & 0.20 & 8.93 & 2.50 & 0.89 & $\mathrm{C}_{3} \mathrm{~S}_{1}$ \\
\hline $\mathrm{T}_{3}$ & 7.22 & 2.50 & 5.07 & 0.37 & 21.83 & 17.50 & 2.33 & $\mathrm{C}_{4} \mathrm{~S}_{1}$ \\
\hline $\mathrm{T}_{4}$ & 7.30 & 5.00 & 5.42 & 0.59 & 40.56 & 30.00 & 3.57 & $\mathrm{C}_{4} \mathrm{~S}_{1}$ \\
\hline
\end{tabular}

*Irrigation waters were classified according to ABD system

Table 2. Salts and the amounts used in $\mathrm{T}_{3}$ and $\mathrm{T}_{4}$ subjects $\left(\mathrm{g} \mathrm{L}^{-1}\right)$

\begin{tabular}{lcccc}
\hline EC (electrical conductivity) & SAR (sodium absorption ratio) & $\mathrm{NaCl}$ & $\mathrm{MgSO}_{4}$ & $\mathrm{CaCl}_{2}$ \\
\hline 2500 & 0.69 & 0.14 & 0.22 & 1.14 \\
5000 & 0.56 & 0.16 & 0.27 & 2.47 \\
\hline
\end{tabular}


in Table 4. The highest yield was obtained from $\mathrm{T}_{1} \mathrm{~S}_{2}$ subject with the value of $109430 \mathrm{~kg} \mathrm{ha}^{-1}$ and the lowest yield was obtained from $\mathrm{T}_{4} \mathrm{~S}_{1}$ subject with the value of $67600 \mathrm{~kg} \mathrm{ha}^{-1}$ in 2014. In the second year, the highest yield was obtained from $T_{1} S_{2}$ subject with the value of $108680 \mathrm{~kg} \mathrm{ha}^{-1}$ and the lowest yield was obtained from $\mathrm{T}_{4} \mathrm{~S}_{1}$ subject with the value of $46820 \mathrm{~kg} \mathrm{ha}^{-1}$. Similarly, in 2016, the highest and the lowest values were obtained from $\mathrm{T}_{1} \mathrm{~S}_{2}$ and $\mathrm{T}_{4} \mathrm{~S}_{1}$ subjects with the values of $109070 \mathrm{~kg} \mathrm{ha}^{-1}$ and $54070 \mathrm{~kg} \mathrm{ha}^{-1}$, respectively.

According to the analyses which the three year data were evaluated separately and collectively, it was determined that the yield was effected from irrigation water levels $(P<0.01)$. In $S_{2}$ and $S_{3}$ irrigations, the differences between the yields was not statistically significant and the yield was low in $\mathrm{S}_{1}$ irrigation level. According to the collective variance analysis, the yield amounts were 91700 and $93423 \mathrm{~kg} \mathrm{ha}^{-1}$ in $S_{2}$ and $S_{3}$ irrigations and the yield amount was lower and determined as $64913 \mathrm{~kg} \mathrm{ha}^{-1}$ in $\mathrm{S}_{1}$ irrigation.

According to the analyses which the three year data were evaluated separately and collectively, it was determined that the salinity of the irrigation water effected the yield $(P<0.01)$ (Table 4$)$. In the first year of the experiment, it was determined that the yield decreased as the irrigation water salinity increased but the differences between the yield amounts in $T_{3}$ and $T_{4}$ salinity levels were not statistically significant $(P>0.01)$. In the second year, the effect of the irrigation water salinity on the yield was different from the first year and the differences between the yield amounts of the plants irrigated by the waters on $T_{1}, T_{2}, T_{3}$ and $T_{4}$ salinity levels were not statistically significant $(P>0.01)$. In the third year, the yields of the plants irrigated by the waters on $T_{1}$ and $T_{2}$ salinity levels were in a group whereas the yields of the plants irrigated by the waters on $T_{3}$ and $T_{4}$ salinity levels were in another group.

Table 3. Energy equivalents of inputs and outputs in greenhouse production

\begin{tabular}{|c|c|c|}
\hline & Energy equivalents(MJ unit ${ }^{-1}$ ) & References \\
\hline \multicolumn{3}{|l|}{ Inputs } \\
\hline Human labor (h) & 1.96 & (De et al., 2001; Singh, 2002) \\
\hline Machinery $(\mathrm{h})$ & 64.80 & (Singh, 2002; Baran et al., 2016) \\
\hline \multicolumn{3}{|l|}{ Pesticides (kg) } \\
\hline Insecticide & 101.20 & (Rafiee et al., 2010) \\
\hline Fungicide & 216.00 & (Rafiee et al., 2010) \\
\hline \multicolumn{3}{|l|}{ Fertilizer (kg) } \\
\hline Nitrogen & 60.60 & (Singh, 2002) \\
\hline Phosphorus & 11.15 & (Singh, 2002) \\
\hline Potassium & 6.70 & (Singh, 2002) \\
\hline Micro & 120.00 & (Çanakçı and Akıncı, 2006) \\
\hline Farmyard manure (t) & 303.10 & (Yaldız et al., 1993) \\
\hline Seed & 2.36 & (Mihov and Antonova, 2009) \\
\hline Diesel (I) & 56.31 & (De et al., 2001; Singh, 2002) \\
\hline Electricity (kWh) & 3.60 & (Yaldız et al., 1993) \\
\hline Irrigation water $\left(\mathrm{m}^{3}\right)$ & 0.63 & (Yaldız et al., 1993) \\
\hline \multicolumn{3}{|l|}{ Output } \\
\hline Yield (kg) & 0.80 & (Yaldız et al., 1993) \\
\hline
\end{tabular}

Table 4. Effect of irrigation water salinity and irrigation levels on tomato yield in three growing period $\left(\mathrm{kg} \mathrm{ha}^{-1}\right)$

\begin{tabular}{|c|c|c|c|c|c|c|}
\hline \multirow{2}{*}{ Growing period } & \multirow{2}{*}{$\begin{array}{c}\text { Irrigation water } \\
\text { level }\end{array}$} & \multicolumn{5}{|c|}{ Irrigation water salinity } \\
\hline & & $\mathrm{T}_{1}$ & $T_{2}$ & $\mathrm{~T}_{3}$ & $\mathrm{~T}_{4}$ & Average \\
\hline \multirow{4}{*}{2014} & $\mathrm{~S}_{1}$ & 81110 & 74340 & 68650 & 67600 & $72925 \mathrm{~B}$ \\
\hline & $\mathrm{S}_{2}$ & 109430 & 98860 & 83810 & 76540 & $92160 \mathrm{~A}$ \\
\hline & $\mathrm{S}_{3}$ & 101770 & 93380 & 85650 & 86350 & 91788 A \\
\hline & Average & $97437 \mathrm{~A}$ & $88860 \mathrm{~B}$ & $79370 \mathrm{C}$ & $76830 \mathrm{C}$ & \\
\hline \multirow{4}{*}{2015} & $\mathrm{~S}_{1}$ & 70310 & 71130 & 66310 & 46820 & $63643 \mathrm{~B}$ \\
\hline & $\mathrm{S}_{2}$ & 108680 & 105040 & 89000 & 64780 & $91875 \mathrm{~A}$ \\
\hline & $\mathrm{S}_{3}$ & 102520 & 104120 & 103760 & 81400 & $97950 \mathrm{~A}$ \\
\hline & Average & $93837 \mathrm{~A}$ & $93430 \mathrm{~A}$ & $86357 \mathrm{~A}$ & $64333 \mathrm{~B}$ & \\
\hline \multirow{4}{*}{2016} & $\mathrm{~S}_{1}$ & 60650 & 60460 & 57500 & 54070 & $58170 \mathrm{~B}$ \\
\hline & $\mathrm{S}_{2}$ & 109070 & 107410 & 75830 & 71940 & $91063 \mathrm{~A}$ \\
\hline & $\mathrm{S}_{3}$ & 101300 & 100000 & 86200 & 78330 & 91458 A \\
\hline & Average & $90340 \mathrm{~A}$ & $89290 \mathrm{~A}$ & $73177 \mathrm{~B}$ & $68113 \mathrm{~B}$ & \\
\hline \multirow{4}{*}{$\begin{array}{c}\text { Average of the } \\
\text { years }\end{array}$} & $\mathrm{S}_{1}$ & 70690 & 68650 & 64150 & 56160 & $64913 \mathrm{~B}$ \\
\hline & $\mathrm{S}_{2}$ & 109060 & 103770 & 82880 & 71090 & $91700 \mathrm{~A}$ \\
\hline & $\mathrm{S}_{3}$ & 101860 & 99170 & 91870 & 80790 & $93423 \mathrm{~A}$ \\
\hline & Average & $93870 \mathrm{~A}$ & $90530 \mathrm{~A}$ & 79633 В & $69347 \mathrm{C}$ & \\
\hline
\end{tabular}


On the evaluation of the three years data together, it was concluded that the yield amounts decreased by the increase of the irrigation water salinity but there were not differences between the yields obtained on $T_{1}$ and $T_{2}$ salinity levels. In previous studies, Restuccia et al. (2002) obtained the highest yield from $E T=100 \%+$ +irrigation water with $1.6 \mathrm{dS} \mathrm{m}^{-1}$ salinity level in tomato production irrigated with the waters on $1.6 \mathrm{dS} \mathrm{m}^{-1}$ and $6.00 \mathrm{dS} \mathrm{m}^{-1}$ salinity levels in unheated plastic covered greenhouse. In another study, Pascale et al. (2003) stated that it was possible to improve carotenoids and ascorbic acid contents and antioxidant activity of tomato, with an acceptable yield reduction (10\%), by irrigating with saline water containing sea salt up to $4.4 \mathrm{dS} \mathrm{m}^{-1}$ and also they stated that the fruit nutritive value of tomato could be increased by the irrigations with saline irrigation waters. According to Yaylalı (2007), the yield amounts decreased on the ratio of $41 \%$ by the increase of the salinity in the irrigation water (between 0.5 and $2.5 \mathrm{dS} \mathrm{m}^{-1}$ ). According to many researches (Lopez and Satti, 1996; Maas and Grattan, 1999; Kesmez, 2003; Abdel Gawad et al., 2005), it was concluded that the yield amounts in tomato plant decreased by the increase of irrigation water salinity.

When the results were evaluated in terms of irrigation water levels, it was determined that $\mathrm{S}_{1}$ application in all salinity level subjects caused decreases in the yield amounts. $S_{2}$ irrigation application became prominent in $T_{1}$ and $T_{2}$ subjects in terms of yield whereas the yield amounts in $T_{3}$ and $T_{4}$ subjects. The yield amounts were higher in $\mathrm{T}_{1}$ and $\mathrm{T}_{2}$ subjects in $\mathrm{S}_{3}$ irrigation level in accordance with $S_{1}$ and $S_{2}$ irrigation levels.

There were not significant losses in the yield amounts under the $\mathrm{T}_{3}$ salinity levels in $\mathrm{S}_{2}$ irrigation level but the yield amounts decreased when the irrigation level was increased to $S_{3}$ in these salinity levels. On the other hand, the yield amounts increased with $S_{3}$ irrigation on the salinity level of $T_{3}$ and above. Similarly, Flowers et al. (2010) stated that the salinity levels under $\mathrm{T}_{3}$ did not affect the yield amounts and the additional irrigation in high salinity levels had a curative effect on the yield.

\subsection{Input and energy use}

The amounts of the inputs used in $T_{1}$ and $T_{2}$ subjects by sub subjects in greenhouse tomato production are given in Table 5. As seen in Table 5, $7267 \mathrm{~h}$ human labor, $10.50 \mathrm{~h}$ machinery, $25.30 \mathrm{~L}$ diesel fuel, $25 \mathrm{t}$ farmyard manure, $352.50 \mathrm{~kg}$ nitrogen, $122.50 \mathrm{~kg}$ phosphorus, $650.20 \mathrm{~kg}$ potassium, $9.10 \mathrm{~kg}$ insecticides, $4.10 \mathrm{~kg}$ fungicides and $11.00 \mathrm{~kg}$ seed per hectare were used for tomato production in $T_{1}$ and $T_{2}$ subjects. Besides, $2400 \mathrm{~m}^{3}$ water and $520.20 \mathrm{kWh}$ electricity were used in $S_{1}$ irrigation level, $3340 \mathrm{~m}^{3}$ water and $740.60 \mathrm{kWh}$ electricity were used in $\mathrm{S}_{2}$ irrigation level and $4290 \mathrm{~m}^{3}$ water and $951.20 \mathrm{kWh}$ electricity were used in $\mathrm{S}_{3}$ irrigation level.

The amounts of the inputs used in $T_{3}$ and $T_{4}$ subjects by sub subjects in greenhouse tomato production are given in Table 6 and Table 7 , respectively. In $T_{3}$ and $T_{4}$ subjects, the input amounts used per hectare in $S_{1}, S_{2}$ and $S_{3}$ irrigation levels were the same as the input amounts in $T_{1}$ and $T_{2}$ subjects and differently, micronutrient elements were used in $T_{3}$ and $T_{4}$ subjects. In $T_{3}$ subject, $3.33 \mathrm{~kg}, 4.59 \mathrm{~kg}$ and $6.22 \mathrm{~kg}$ micronutrient element application per hectare was done in $S_{1}, S_{2}$ and $S_{3}$ irrigation levels whereas in $\mathrm{T}_{4}$ subject, $7.17 \mathrm{~kg}$, $10.06 \mathrm{~kg}$ and $12.78 \mathrm{~kg}$ micronutrient element application per hectare was done in $S_{1}, S_{2}$ and $S_{3}$ irrigation levels, respectively.

The energy equivalents of the inputs used in $T_{1}$ and $T_{2}$ subjects are given in Table 8 , the energy equivalents of the inputs used in $\mathrm{T}_{3}$ subject are given in Table 9 and the energy equivalents of the inputs used in $\mathrm{T}_{4}$ subject are given in Table 10. In all subjects, the energy equivalents of the inputs were calculated as $14243.32 \mathrm{MJ}$ human labor,

Table 5. Use of inputs in $T_{1}$ and $T_{2}$ subjects for greenhouse tomato production

\begin{tabular}{|c|c|c|c|}
\hline Inputs & $\mathrm{T}_{1} \mathrm{~S}_{1}-\mathrm{T}_{2} \mathrm{~S}_{1}$ & $\mathrm{~T}_{1} \mathrm{~S}_{2}-\mathrm{T}_{2} \mathrm{~S}_{2}$ & $\mathrm{~T}_{1} \mathrm{~S}_{3}-\mathrm{T}_{2} \mathrm{~S}_{3}$ \\
\hline Human labor (h) & 7267.00 & 7267.00 & 7267.00 \\
\hline Machinery (h) & 10.50 & 10.50 & 10.50 \\
\hline Diesel (L) & 25.30 & 25.30 & 25.30 \\
\hline Farmyard manure $(\mathrm{t})$ & 25.00 & 25.00 & 25.00 \\
\hline \multicolumn{4}{|l|}{ Fertilizer (kg) } \\
\hline Nitrogen & 352.50 & 352.50 & 352.50 \\
\hline Phosphorus & 122.50 & 122.50 & 122.50 \\
\hline Potassium & 650.20 & 650.20 & 650.20 \\
\hline Micro & 0.00 & 0.00 & 0.00 \\
\hline \multicolumn{4}{|l|}{ Pesticides (kg) } \\
\hline Insecticide & 9.10 & 9.10 & 9.10 \\
\hline Fungicide & 4.10 & 4.10 & 4.10 \\
\hline Water $\left(m^{3}\right)$ & 2400.00 & 3340.00 & 4290.00 \\
\hline Electricity (kWh) & 520.20 & 740.60 & 951.20 \\
\hline Seed $(\mathrm{kg})$ & 11.00 & 11.00 & 11.00 \\
\hline
\end{tabular}

$\mathrm{S}_{1}=70 \%, \mathrm{~S}_{2}=100 \%, \mathrm{~S}_{3}=130 \%, \mathrm{~T}_{1}=0.38 \mathrm{dS} \mathrm{m}^{-1}, \mathrm{~T}_{2}=1.1 \mathrm{dS} \mathrm{m}^{-1}, \mathrm{~T} 3=2.5 \mathrm{dS} \mathrm{m}^{-1}$ 
Table 6. Use of inputs in $\mathrm{T}_{3}$ subject for greenhouse tomato production

\begin{tabular}{|c|c|c|c|}
\hline Inputs & $\mathrm{T}_{3} \mathrm{~S}_{1}$ & $\mathrm{~T}_{3} \mathrm{~S}_{2}$ & $\mathrm{~T}_{3} \mathrm{~S}_{3}$ \\
\hline Human labor (h) & 7267.00 & 7267.00 & 7267.00 \\
\hline Machinery (h) & 10.50 & 10.50 & 10.50 \\
\hline Diesel $(\mathrm{L})$ & 25.30 & 25.30 & 25.30 \\
\hline Farmyard manure $(\mathrm{t})$ & 25.00 & 25.00 & 25.00 \\
\hline \multicolumn{4}{|l|}{ Fertilizer (kg) } \\
\hline Nitrogen & 352.50 & 352.50 & 352.50 \\
\hline Phosphorus & 122.50 & 122.50 & 122.50 \\
\hline Potassium & 650.20 & 650.20 & 650.20 \\
\hline Micro & 3.33 & 4.59 & 6.22 \\
\hline \multicolumn{4}{|l|}{ Pesticides (kg) } \\
\hline Insecticide & 9.10 & 9.10 & 9.10 \\
\hline Fungicide & 4.10 & 4.10 & 4.10 \\
\hline Water $\left(\mathrm{m}^{3}\right)$ & 2400.00 & 3340.00 & 4290.00 \\
\hline Electricity (kWh) & 520.20 & 740.60 & 951.20 \\
\hline Seed $(\mathrm{kg})$ & 11.00 & 11.00 & 11.00 \\
\hline
\end{tabular}

$\mathrm{S}_{1}=70 \%, \mathrm{~S}_{2}=100 \%, \mathrm{~S}_{3}=130 \%, \mathrm{~T}_{3}=2.5 \mathrm{dS} \mathrm{m}^{-1}$

Table 7. Use of inputs in T4 subject for greenhouse tomato production

\begin{tabular}{|c|c|c|c|}
\hline Inputs & $\mathrm{T}_{4} \mathrm{~S}_{1}$ & $\mathrm{~T}_{4} \mathrm{~S}_{2}$ & $\mathrm{~T}_{4} \mathrm{~S}_{3}$ \\
\hline Human labor (h) & 7267.00 & 7267.00 & 7267.00 \\
\hline Machinery $(\mathrm{h})$ & 10.50 & 10.50 & 10.50 \\
\hline Diesel (L) & 25.30 & 25.30 & 25.30 \\
\hline Farmyard manure $(\mathrm{t})$ & 25.00 & 25.00 & 25.00 \\
\hline \multicolumn{4}{|l|}{ Fertilizer $(\mathrm{kg})$} \\
\hline Nitrogen & 352.50 & 352.50 & 352.50 \\
\hline Phosphorus & 122.50 & 122.50 & 122.50 \\
\hline Potassium & 650.20 & 650.20 & 650.20 \\
\hline Micro & 7.17 & 10.06 & 12.78 \\
\hline \multicolumn{4}{|l|}{ Pesticides (kg) } \\
\hline Insecticide & 9.10 & 9.10 & 9.10 \\
\hline Fungicide & 4.10 & 4.10 & 4.10 \\
\hline Water $\left(\mathrm{m}^{3}\right)$ & 2400.00 & 3340.00 & 4290.00 \\
\hline Electricity (kWh) & 520.20 & 740.60 & 951.20 \\
\hline Seed $(\mathrm{kg})$ & 11.00 & 11.00 & 11.00 \\
\hline
\end{tabular}

$\mathrm{S}_{1}=70 \%, \mathrm{~S}_{2}=100 \%, \mathrm{~S}_{3}=130 \%, \mathrm{~T}_{3}=2.5 \mathrm{dS} \mathrm{m}^{-1} \mathrm{~T}_{4}=5.0 \mathrm{dS} \mathrm{m^{-1 }}$

680.40 MJ machinery, $1424.64 \mathrm{MJ}$ diesel, $7577.50 \mathrm{MJ}$ farmyard manure, $21361.50 \mathrm{MJ}$ nitrogen, $1365.88 \mathrm{MJ}$ phosphorus, $4356.34 \mathrm{MJ}$ potassium, $920.92 \mathrm{MJ}$ insecticide, $885.60 \mathrm{MJ}$ fungicide and $25.96 \mathrm{MJ}$ seed per hectare. In all subjects, $1512 \mathrm{MJ}$ water and $1872.72 \mathrm{MJ}$ electricity was used in $S_{1}$ irrigation level, 2 104.20 MJ water and 2 666.16 MJ electricity was used in $\mathrm{S}_{2}$ irrigation level and $2702.70 \mathrm{MJ}$ water and $3424.32 \mathrm{MJ}$ electricity was used in $\mathrm{S}_{3}$ irrigation level, The energy equivalents of micronutrient elements were determined as $399.84 \mathrm{MJ}$ in $\mathrm{S}_{1}$ irrigation level, 550.80 MJ in $\mathrm{S}_{2}$ irrigation level and $745.92 \mathrm{MJ}$ in $\mathrm{S}_{3}$ irrigation level in $\mathrm{T}_{3}$ subject whereas they were determined as $860.44 \mathrm{MJ}$, $1206.70 \mathrm{MJ}$ and $1534.03 \mathrm{MJ}$ in $S_{1}, S_{2}$ and $S_{3}$ irrigation levels in $\mathrm{T}_{4}$ subject, respectively (Table 8, 9, 10).

When all the main and sub subjects were examined, it was determined that nitrogen consumed the most energy use in green house tomato production, followed by human labor and farmyard manure.
The output values of greenhouse tomato production and the energy equivalents by the main and sub subjects are given in Table 11. Based on the energy outputs, it was noticed that the highest energy outputs in greenhouse tomato production were obtained from $T_{1} S_{2}, T_{2} S_{2}$ and $T_{1} S_{3}$ subjects with the values as 87248,83 016, and $81488 \mathrm{MJ}$, respectively. The lowest energy outputs were obtained from $\mathrm{T}_{4} \mathrm{~S}_{1}, \mathrm{~T}_{3} \mathrm{~S}_{1}, \mathrm{~T}_{2} \mathrm{~S}_{1}$ and $\mathrm{T}_{1} \mathrm{~S}_{1}$ subjects. It was determined that the energy equivalents of the yield were lower in $S_{1}$ irrigation application.

The energy parameters by the main and sub plots are given in Table 12. Energy use efficiency was found as 1.01, 1.51, and 1.38 in $T_{1}$ subject in $\mathrm{S}_{1}, \mathrm{~S}_{2}$ and $\mathrm{S}_{3}$ irrigation levels, respectively. Energy productivity points out the crop quantity per energy use and it was calculated as 1.26, 1.89, and $1.73 \mathrm{~kg} \mathrm{MJ}^{-1}$ in $T_{1}$ subject in $S_{1}, S_{2}$ and $S_{3}$ irrigation levels, respectively. Specific energy points out the used energy quantity per crop and this coefficient was found as $0.80,0.53$, and $0.58 \mathrm{MJ} \mathrm{kg}^{-1}$ in $\mathrm{T}_{1}$ subject in $S_{1}, S_{2}$ and $S_{3}$ irrigation levels, respectively. Net energy points out the difference 
Table 8. Energy equivalents in $\mathrm{T}_{1}$ and $\mathrm{T}_{2}$ subjects for greenhouse tomato production ( $M \mathrm{~J} \mathrm{ha}^{-1}$ )

\begin{tabular}{|c|c|c|c|c|c|c|}
\hline \multirow[b]{2}{*}{ Inputs } & \multicolumn{2}{|c|}{$\mathrm{T}_{1} \mathrm{~S}_{1}-\mathrm{T}_{2} \mathrm{~S}_{1}$} & \multicolumn{2}{|c|}{$\mathrm{T}_{1} \mathrm{~S}_{2}-\mathrm{T}_{2} \mathrm{~S}_{2}$} & \multicolumn{2}{|c|}{$\mathrm{T}_{1} \mathrm{~S}_{3}-\mathrm{T}_{2} \mathrm{~S}_{3}$} \\
\hline & $\begin{array}{l}\text { Energy } \\
\text { equivalent }\end{array}$ & $\%$ & $\begin{array}{c}\text { Energy } \\
\text { equivalent }\end{array}$ & $\%$ & $\begin{array}{c}\text { Energy } \\
\text { equivalent }\end{array}$ & $\%$ \\
\hline Human labor (h) & 14243.32 & 25.33 & 14243.32 & 24.72 & 14243.32 & 24.15 \\
\hline Machinery $(\mathrm{h})$ & 680.40 & 1.21 & 680.40 & 1.18 & 680.40 & 1.15 \\
\hline Diesel $(L)$ & 1424.64 & 2.53 & 1424.64 & 2.47 & 1424.64 & 2.42 \\
\hline $\begin{array}{l}\text { Farmyard manure }(\mathrm{t}) \\
\text { Fertilizer }(\mathrm{kg})\end{array}$ & 7577.50 & 13.48 & 7577.50 & 13.15 & 7577.50 & 12.85 \\
\hline Nitrogen & 21361.50 & 37.99 & 21361.50 & 37.08 & 21361.50 & 36.22 \\
\hline Phosphorus & 1365.88 & 2.43 & 1365.88 & 2.37 & 1365.88 & 2.32 \\
\hline Potassium & 4356.34 & 7.75 & 4356.34 & 7.56 & 4356.34 & 7.39 \\
\hline Micro & 0.00 & 0.00 & 0.00 & 0.00 & 0.00 & 0.00 \\
\hline Pesticides (kg) & & & & & & \\
\hline Insecticide & 920.92 & 1.64 & 920.92 & 1.60 & 920.92 & 1.56 \\
\hline Fungicide & 885.60 & 1.58 & 885.60 & 1.54 & 885.60 & 1.50 \\
\hline Water $\left(m^{3}\right)$ & 1512.00 & 2.69 & 2104.20 & 3.65 & 2702.70 & 4.58 \\
\hline Electricity (kWh) & 1872.72 & 3.33 & 2666.16 & 4.63 & 3424.32 & 5.81 \\
\hline Seed $(\mathrm{kg})$ & 25.96 & 0.05 & 25.96 & 0.05 & 25.96 & 0.04 \\
\hline Total energy input & 56226.78 & 100.00 & 57612.42 & 100.00 & 58969.08 & 100.00 \\
\hline
\end{tabular}

$\mathrm{S}_{1}=70 \%, \mathrm{~S}_{2}=100 \%, \mathrm{~S}_{3}=130 \%, \mathrm{~T}_{1}=0.38 \mathrm{dS} \mathrm{m}^{-1}, \mathrm{~T}_{2}=1.1 \mathrm{dS} \mathrm{m}^{-1}, \mathrm{~T}_{3}=2.5 \mathrm{dS} \mathrm{m}^{-1}$

Table 9. Energy equivalents in T3 subject for greenhouse tomato production ( $\mathrm{MJ} \mathrm{ha}^{-1}$ )

\begin{tabular}{|c|c|c|c|c|c|c|}
\hline \multirow[b]{2}{*}{ Inputs } & \multicolumn{2}{|c|}{$\mathrm{T}_{3} \mathrm{~S}_{1}$} & \multicolumn{2}{|c|}{$\mathrm{T}_{3} \mathrm{~S}_{2}$} & \multicolumn{2}{|c|}{$\mathrm{T}_{3} \mathrm{~S}_{3}$} \\
\hline & $\begin{array}{c}\text { Energy } \\
\text { equivalent }\end{array}$ & $\%$ & $\begin{array}{c}\text { Energy } \\
\text { equivalent }\end{array}$ & $\%$ & $\begin{array}{c}\text { Energy } \\
\text { equivalent }\end{array}$ & $\%$ \\
\hline Human labor (h) & 14243.32 & 25.15 & 14243.32 & 24.49 & 14243.32 & 23.85 \\
\hline Machinery (h) & 680.40 & 1.20 & 680.40 & 1.17 & 680.40 & 1.14 \\
\hline Diesel (L) & 1424.64 & 2.52 & 1424.64 & 2.45 & 1424.64 & 2.39 \\
\hline $\begin{array}{l}\text { Farmyard manure }(\mathrm{t}) \\
\text { Fertilizer }(\mathrm{kg})\end{array}$ & 7577.50 & 13.38 & 7577.50 & 13.03 & 7577.50 & 12.69 \\
\hline Nitrogen & 21361.50 & 37.72 & 21361.50 & 36.73 & 21361.50 & 35.77 \\
\hline Phosphorus & 1365.88 & 2.41 & 1365.88 & 2.35 & 1365.88 & 2.29 \\
\hline Potassium & 4356.34 & 7.69 & 4356.34 & 7.49 & 4356.34 & 7.30 \\
\hline Micro & 399.84 & 0.71 & 550.80 & 0.95 & 745.92 & 1.25 \\
\hline Pesticides (kg) & & & & & & \\
\hline Insecticide & 920.92 & 1.63 & 920.92 & 1.58 & 920.92 & 1.54 \\
\hline Fungicide & 885.60 & 1.56 & 885.60 & 1.52 & 885.60 & 1.48 \\
\hline Water $\left(\mathrm{m}^{3}\right)$ & 1512.00 & 2.67 & 2104.20 & 3.62 & 2702.70 & 4.53 \\
\hline Electricity (kWh) & 1872.72 & 3.31 & 2666.16 & 4.58 & 3424.32 & 5.73 \\
\hline Seed $(\mathrm{kg})$ & 25.96 & 0.05 & 25.96 & 0.04 & 25.96 & 0.04 \\
\hline Total energy input & 56626.62 & 100.00 & 58163.22 & 100.00 & 59715.00 & 100.00 \\
\hline
\end{tabular}

$\mathrm{S}_{1}=70 \%, \mathrm{~S}_{2}=100 \%, \mathrm{~S}_{3}=130 \%, \mathrm{~T}_{3}=2.5 \mathrm{dS} \mathrm{m}^{-1}$

Table 10. Energy equivalents in $\mathrm{T}_{4}$ subject for greenhouse tomato production ( $\mathrm{MJ} \mathrm{ha}^{-1}$ )

\begin{tabular}{|c|c|c|c|c|c|c|}
\hline \multirow[b]{2}{*}{ Inputs } & \multicolumn{2}{|c|}{$\mathrm{T}_{4} \mathrm{~S}_{1}$} & \multicolumn{2}{|c|}{$\mathrm{T}_{4} \mathrm{~S}_{2}$} & \multicolumn{2}{|c|}{$\mathrm{T}_{4} \mathrm{~S}_{3}$} \\
\hline & $\begin{array}{c}\text { Energy } \\
\text { equivalent }\end{array}$ & $\%$ & $\begin{array}{c}\text { Energy } \\
\text { equivalent }\end{array}$ & $\%$ & $\begin{array}{c}\text { Energy } \\
\text { equivalent }\end{array}$ & $\%$ \\
\hline Human labor (h) & 14243.32 & 24.95 & 14243.32 & 24.22 & 14243.32 & 23.54 \\
\hline Machinery (h) & 680.40 & 1.19 & 680.40 & 1.16 & 680.40 & 1.12 \\
\hline Diesel (L) & 1424.64 & 2.50 & 1424.64 & 2.42 & 1424.64 & 2.35 \\
\hline Farmyard manure $(\mathrm{t})$ & 7577.50 & 13.27 & 7577.50 & 12.88 & 7577.50 & 12.52 \\
\hline \multicolumn{7}{|l|}{ Fertilizer $(\mathrm{kg})$} \\
\hline Nitrogen & 21361.50 & 37.42 & 21361.50 & 36.32 & 21361.50 & 35.31 \\
\hline Phosphorus & 1365.88 & 2.39 & 1365.88 & 2.32 & 1365.88 & 2.26 \\
\hline Potassium & 4356.34 & 7.63 & 4356.34 & 7.41 & 4356.34 & 7.20 \\
\hline Micro & 860.44 & 1.51 & 1206.70 & 2.05 & 1534.03 & 2.54 \\
\hline \multicolumn{7}{|l|}{ Pesticides (kg) } \\
\hline Insecticide & 920.92 & 1.61 & 920.92 & 1.57 & 920.92 & 1.52 \\
\hline Fungicide & 885.60 & 1.55 & 885.60 & 1.51 & 885.60 & 1.46 \\
\hline Water $\left(\mathrm{m}^{3}\right)$ & 1512.00 & 2.65 & 2104.20 & 3.58 & 2702.70 & 4.47 \\
\hline Electricity (kWh) & 1872.72 & 3.28 & 2666.16 & 4.53 & 3424.32 & 5.66 \\
\hline Seed $(\mathrm{kg})$ & 25.96 & 0.05 & 25.96 & 0.04 & 25.96 & 0.04 \\
\hline Total energy input & 57087.21 & 100.00 & 58819.11 & 100.00 & 60503.11 & 100.00 \\
\hline
\end{tabular}

$\mathrm{S}_{1}=70 \%, \mathrm{~S}_{2}=100 \%, \mathrm{~S}_{3}=130 \%, \mathrm{~T}_{3}=2.5 \mathrm{dS} \mathrm{m}^{-1} \mathrm{~T}_{4}=5.0 \mathrm{dS} \mathrm{m}^{-1}$ 
Table 11. Yield (output) amounts and energy equivalents in greenhouse tomato production

\begin{tabular}{|c|c|c|c|c|c|c|}
\hline \multirow[b]{2}{*}{ Subjects } & \multicolumn{2}{|r|}{$\mathrm{S}_{1}$} & \multicolumn{2}{|r|}{$\mathrm{S}_{2}$} & \multicolumn{2}{|r|}{$\mathrm{S}_{3}$} \\
\hline & $\begin{array}{c}\text { Yield } \\
\left(\mathrm{kg} \mathrm{ha}^{-1}\right)\end{array}$ & $\begin{array}{c}\text { Energy equivalent } \\
\left(\mathrm{MJ} \mathrm{ha}^{-1}\right)\end{array}$ & $\begin{array}{c}\text { Yield } \\
\left(\mathrm{kg} \mathrm{ha}^{-1}\right)\end{array}$ & $\begin{array}{l}\text { Energy equivalent } \\
\left(\mathrm{MJ} \mathrm{ha}^{-1}\right)\end{array}$ & $\begin{array}{c}\text { Yield } \\
\left(\mathrm{kg} \mathrm{ha}^{-1}\right)\end{array}$ & $\begin{array}{c}\text { Energy equivalent } \\
\left(\mathrm{MJ} \mathrm{ha}^{-1}\right)\end{array}$ \\
\hline$T_{1}$ & 70690.00 & 56552.00 & 109060.00 & 87248.00 & 101860.00 & 81488.00 \\
\hline $\mathrm{T}_{2}$ & 68650.00 & 54920.00 & 103770.00 & 83016.00 & 99170.00 & 79336.00 \\
\hline $\mathrm{T}_{3}$ & 64150.00 & 51320.00 & 82880.00 & 66304.00 & 91870.00 & 73496.00 \\
\hline $\mathrm{T}_{4}$ & 56160.00 & 44928.00 & 71090.00 & 56872.00 & 80790.00 & 64632.00 \\
\hline
\end{tabular}

$\mathrm{S}_{1}=70 \%, \mathrm{~S}_{2}=100 \%, \mathrm{~S}_{3}=130 \%, \mathrm{~T}_{1}=0.38 \mathrm{dS} \mathrm{m}^{-1}, \mathrm{~T}_{2}=1.1 \mathrm{dS} \mathrm{m}^{-1}, \mathrm{~T}_{3}=2.5 \mathrm{dS} \mathrm{m}^{-1} \mathrm{~T}_{4}=5.0 \mathrm{dS} \mathrm{m}^{-1}$

Table 12. Energy parameters in greenhouse tomato production

\begin{tabular}{lcccr}
\hline Subjects & Energy use efficiency & Energy productivity $\left(\mathrm{kg} \mathrm{MJ}^{-1}\right)$ & Specific energy $\left(\mathrm{MJ} \mathrm{kg}^{-1}\right)$ & Net energy $\left(\mathrm{MJ} \mathrm{ha}^{-1}\right)$ \\
\hline $\mathrm{T}_{1} \mathrm{~S}_{1}$ & 1.01 & 1.26 & 0.80 & 325.22 \\
$\mathrm{~T}_{1} \mathrm{~S}_{2}$ & 1.51 & 1.89 & 0.53 & 29635.58 \\
$\mathrm{~T}_{1} \mathrm{~S}_{3}$ & 1.38 & 1.73 & 0.58 & 22518.92 \\
$\mathrm{~T}_{2} \mathrm{~S}_{1}$ & 0.98 & 1.22 & 0.82 & -1306.78 \\
$\mathrm{~T}_{2} \mathrm{~S}_{2}$ & 1.44 & 1.80 & 0.56 & 25403.58 \\
$\mathrm{~T}_{2} \mathrm{~S}_{3}$ & 1.35 & 1.68 & 0.59 & 20366.92 \\
$\mathrm{~T}_{3} \mathrm{~S}_{1}$ & 0.91 & 1.13 & 0.88 & -5306.62 \\
$\mathrm{~T}_{3} \mathrm{~S}_{2}$ & 1.14 & 1.42 & 0.70 & 8140.78 \\
$\mathrm{~T}_{3} \mathrm{~S}_{3}$ & 1.23 & 1.54 & 0.65 & 13781.00 \\
$\mathrm{~T}_{4} \mathrm{~S}_{1}$ & 0.79 & 0.98 & 1.02 & -12159.21 \\
$\mathrm{~T}_{4} \mathrm{~S}_{2}$ & 0.97 & 1.21 & 0.83 & -1947.11 \\
$\mathrm{~T}_{4} \mathrm{~S}_{3}$ & 1.07 & 1.34 & 0.75 & 4128.89 \\
\hline $\mathrm{S}_{1}=70 \%$ & & &
\end{tabular}

$\mathrm{S}_{1}=70 \%, \mathrm{~S}_{2}=100 \%, \mathrm{~S}_{3}=130 \%, \mathrm{~T}_{1}=0.38 \mathrm{dS} \mathrm{m}^{-1}, \mathrm{~T}_{2}=1.1 \mathrm{dS} \mathrm{m}^{-1}, \mathrm{~T}_{3}=2.5 \mathrm{dS} \mathrm{m}^{-1} \mathrm{~T}_{4}=5.0 \mathrm{dS} \mathrm{m}^{-1}$

between the used energy and the output energy. Net energy was calculated as 325.22, 29 635.58, and $22518.92 \mathrm{MJ} \mathrm{ha}^{-1}$ in $\mathrm{T}_{1} \mathrm{~S}_{1}, \mathrm{~T}_{1} \mathrm{~S}_{2}$ and $\mathrm{T}_{1} \mathrm{~S}_{3}$ subjects, respectively.

Energy use efficiency was found as $0.98,1.44$, and 1.35 in $T_{2}$ subject in $S_{1}, S_{2}$ and $S_{3}$ irrigation levels, respectively. Energy productivity was calculated as 1.22, 1.80 , and $1.68 \mathrm{~kg} \mathrm{MJ}^{-1}$ in $\mathrm{T}_{2}$ subject in $S_{1}, S_{2}$ and $S_{3}$ irrigation levels, respectively. Specific energy was found as 0.82 , 0.56 , and $0.59 \mathrm{MJ} \mathrm{kg}^{-1}$ in $\mathrm{T}_{2}$ subject in $\mathrm{S}_{1}, \mathrm{~S}_{2}$ and $\mathrm{S}_{3}$ irrigation levels, respectively. Net energy was calculated as $-1306.78,25403.58$, and $20366.92 \mathrm{MJ}^{-1}$ in $\mathrm{T}_{2} \mathrm{~S}_{1}, \mathrm{~T}_{2} \mathrm{~S}_{2}$ and $\mathrm{T}_{2} \mathrm{~S}_{3}$ subjects, respectively.

Energy use efficiency was found as $0.91,1.14$, and 1.23 in $T_{3}$ subject in $S_{1}, S_{2}$ and $S_{3}$ irrigation levels, respectively. Energy productivity was calculated as 1.13,, 1.42 , and $1.54 \mathrm{~kg} \mathrm{MJ}^{-1}$ in $\mathrm{T}_{3}$ subject in $S_{1}, S_{2}$ and $S_{3}$ irrigation levels, respectively. Specific energy was found as 0.88 , 0.70 , and $0.65 \mathrm{MJ} \mathrm{kg}^{-1}$ in $T_{3}$ subject in $S_{1}, S_{2}$ and $S_{3}$ irrigation levels, respectively. Net energy was calculated as $-5306.62, \quad 8140.78$, and $13781 \mathrm{MJ}^{-1}$ in $\mathrm{T}_{3} \mathrm{~S}_{1}, \mathrm{~T}_{3} \mathrm{~S}_{2}$ and $\mathrm{T}_{3} \mathrm{~S}_{3}$ subjects, respectively.

Energy use efficiency was found as $0.79,0.97$ and 1.07 in $T_{4}$ subject in $S_{1}, S_{2}$ and $S_{3}$ irrigation levels, respectively. Energy productivity was calculated as $0.98,1.21$, and $1.34 \mathrm{~kg} \mathrm{MJ}^{-1}$ in $\mathrm{T}_{4}$ subject in $S_{1}, S_{2}$ and $S_{3}$ irrigation levels, respectively. Specific energy was found as 1.02 , 0.83 , and $0.75 \mathrm{MJ} \mathrm{kg}^{-1}$ in $\mathrm{T}_{4}$ subject in $\mathrm{S}_{1}, \mathrm{~S}_{2}$ and $\mathrm{S}_{3}$ irrigation levels, respectively. Net energy was calculated as $-12159.21,-1947.11$, and $4128.89 \mathrm{MJ} \mathrm{ha}^{-1}$ in $\mathrm{T}_{4} \mathrm{~S}_{1}, \mathrm{~T}_{4} \mathrm{~S}_{2}$ and $\mathrm{T}_{4} \mathrm{~S}_{3}$ subjects, respectively.
The best result was obtained from $\mathrm{T}_{1} \mathrm{~S}_{2}$ subject in terms of energy parameters and $T_{2} S_{2}, T_{1} S_{3}$ and $\mathrm{T}_{2} \mathrm{~S}_{3}$ subjects followed this. When evaluated in terms of irrigation water levels, $\mathrm{S}_{1}$ irrigation level in all salinity level subjects caused decreases in energy use efficiency, energy productivity and net energy and increase in specific energy. The best results were obtained from $T_{1} S_{1}$ subjects within the subjects in which deficient water was applied and the lowest values were obtained from $\mathrm{T}_{4} \mathrm{~S}_{1}$ subject. It was determined that the energy use efficiency decreased as the salinity level increased. Mihov and Tringovska (2010) investigated the effect of different organic fertilizer applications on energy use efficiency of greenhouse tomato farming and they determined the energy use efficiencies as 0.92 , 1.19 and 1.11 , respectively. They concluded that the best application was $1 \mathrm{~L} \mathrm{ha}^{-1}$ organic fertilizing application. In previous studies conducted in greenhouse tomato farming, the energy use efficiencies were determined as 1.26 (Özkan et al., 2004), 0.18 (Rezvani Moghaddam et al., 2011), 0.92 (Taki et al., 2012), 0.85 (Kuswardhani et al., 2013), 0.75 (Mirasi et al., 2015), 0.52 (Dimitrijević et al., 2015), 0.92, 1.48 and 0.99 (Shamsabadi et al., 2017) and 0.75 (Yelmen et al., 2019).

The distributions of the inputs according to the direct, indirect, renewable and non-renewable energy groups are given in Table 13. In all subjects, the ratios of direct energy in total energy were determined to be lower than the ratios of indirect energy in total energy. The ratios of the direct energy in total energy were the lowest in $S_{1}$ irrigation applications in all salinity level subjects.

Renewable energy sources are nonconsumable energy sources and they do not damage the nature. Non-renewable energy sources 
are limited and a great majority of these sources damage the nature. In the research area, in all subjects, the ratios of renewable energy in total energy were determined to be lower than the ratios of non-renewable energy in total energy. The ratio of renewable energy in total energy was the lowest in $T_{4}$ subject in which the salinity level was the highest.

\section{Conclusion}

Yield and energy use efficiency of tomato plant grown in green house conditions and irrigated by drip irrigation method in different salinity and water levels were calculated and the optimum irrigation application was determined in the research area. When the three year data were evaluated collectively, it was determined that the yield amounts decreased in the ratios of $3.6 \%, 15.2 \%$ and $26.1 \%$ when the irrigation water salinity increased to $T_{2}, T_{3}$, and $T_{4}$ from $T_{1}$, respectively. The best result was obtained from $T_{1} S_{2}$ subject in terms of yield and energy use efficiency. Energy output/input ratio was found as 1.51 in $T_{1} S_{2}$ subject and it was concluded that the inputs were used efficiently according to the other subjects. Energy output/input ratio was found as 1.44 in $\mathrm{T}_{2} \mathrm{~S}_{2}$ subject and this value was adjacent to the value of $\mathrm{T}_{1} \mathrm{~S}_{2}$ subject. Usage of marginal water in the agriculture is essential as a result of the restricted and polluted water sources in the region. According to the results of this study, the yield amounts and energy use efficiency of $T_{2} S_{2}$ subject were adjacent to $T_{1} S_{2}$ subject even though $\mathrm{T}_{1} \mathrm{~S}_{2}$ subject came to the forefront. This result indicates that $T_{2}$ subject, which has $T_{2}$ salinity level and appears in the third class (high saline water) can be used in greenhouse farming as the moisture is high and the effect of salt harm is in the minimum level in greenhouses according to the open field farming. Likewise, the salt concentrations of most of the underground and over ground water sources are between 1.0 and $1.5 \mathrm{dS} \mathrm{m}^{-1}$ and they take part in the third class in terms of salt criteria.

\section{Acknowledgements}

We would like to thank TAGEM (Project Number: TAGEM/TSKAD/14/A13/B02/08) for their financial support to this study.

\section{References}

Abdel Gawad, G., Arslan, A., Gaihbe, A., \& Kadouri F. (2005). The effects of saline irrigation water management and salt tolerant tomato varieties on sustainable production of tomato in Syria (19992002). Agricultural Water Management, 78:39-53.

Anonymous (2018a). http://bahcebitkileri.cu.edu.tr/uplod/ nturemis/turkiyeortualti.pdf (Data accessed April 25, 2018).

Anonymous (2018b). www.tarim.gov.tr (Date accessed April 25, 2018).
Atay, A.N. (2006). Harran ovası koşullarında damla sulama sistemi ile sulanan biberin tuza dayanımının belirlenmesi. Yüksek Lisans Tezi, Harran Üniversitesi, Şanlıurfa (in Turkish).

Baran, M.F., \& Gökdoğan, O. (2014). Karpuz ve kavun yetiştiriciliğinde enerji girdi-çıktı analizi: Kırklareli ili örneği. Anadolu Tarım Bilimleri Dergisi, 29:217-224.

Baran, M.F., Oğuz, H.İ., \& Gökdoğan, O. (2016). Determining the energy usage efficiency of walnut (Juglans regia L.) cultivation in Turkey. ErwerbsObstbau, 59:77-82.

Bilalis, D., Kamariari, P.E., Karkanis, A., Efthimiadou, A., Zorpas, A., \& Kakabouki, I. (2013). Energy inputs, output and productivity in organic and conventional maize and tomato production, under Mediterranean conditions. Notulae Botanicae Horti Agrobotanica, 41:190-194.

Cuartero, J., \& Fernandez-Munoz, R. (1999). Tomato and salinity. Scientia Horticulture, 78:83-125.

Çanakçı, M., \& Akıncı, I. (2006). Energy use pattern analyses of greenhouse vegetable production. Energy, 31:1243-1256.

Çanakçı, M., Topakçı, M., Akıncı, İ., \& Özmerzi, A. (2005). Energy use pattern of some field crops and vegetable production: case study for Antalya region, Turkey. Energy and Conversion Management, 46:655-666.

Çetin, B., \& Vardar, A. (2008). An economic analysis of energy requirements and input costs for tomato production in Turkey. Renewable Energy, 33:428433.

Darijani, F., Veisi, H., Khoshbakht, K., Liaghati, H., \& Alipour, A. (2012). An input-output energy analysis in intensive agro-ecosystems: a case study of greenhouse cucumber production in Varamin county of Tehran province, Iran. Environmental Sciences, 10:79-90.

De, D., Singh, S., \& Chandra, H. (2001). Technological impact on energy consumption in rain fed soybean cultivation in Madhya Pradesh. Applied Energy, 70:193-213.

Dimitrijević, A., Đević, M., Blažin, S., \& Blažin, D. (2010). Energy efficiency of the lettuce greenhouse production. http:// agris.fao.org/agris -search.do? recordID (Data accessed: November 25, 2019).

Dimitrijević, A., Blažin, S., Blažin, D., \& Ponjican, O. (2015). Energy efficiency of the tomato open field and greenhouse production system. Journal on Processing and Energy in Agriculture, 19:132-135.

Ekinci, K., Akbolat, D., Demircan, V., \& Ekinci, C. (2005). Isparta ili elma üretiminde enerji kullanım etkinliğinin belirlenmesi. 3. Yenilenebilir Enerji Kaynakları Sempozyumu, 19-21 Ekim 2005, Mersin (in Turkish).

Flowers, T.J., Galal, H.K., \& Bromham, L. (2010). Evolution of halophytes: multiple origins of salt tolerance in land plants. Functional Plant Biology, 37:604-612.

Hatırlı, S.A., Özkan, B., \& Fert, C. (2006). Energy inputs and crop yield relationship in greenhouse tomato production. Renewable Energy, 31:427-438.

İbrahim, H.Y. (2011). Energy use pattern in vegetable production under fadama in North Central Nigeria. Tropical and Subtropical Agroecosystems, 14:10191024.

Jadidi, M.R., Sabuni, M.S., Homayounifar, M., \& Mohammadi, A. (2012). Assessment of energy use pattern for tomato production in Iran: A case study from the Marand region. Research in Agricultural Engineering, 58:50-56. 
Kesmez, G.D. (2003). Tuzluluk koşullarının domateste suya dayanıma, su kullanıma ve vejetatif gelişmeye etkisi. Yüksek Lisans Tezi, Ankara Üniversitesi, Ankara (in Turkish).

Kuswardhani, N., Soni, P., \& Shivakoti, G.P. (2013). Comparative energy input-output and financial analyses of greenhouse and open field vegetables production in West Java, Indonesia. Energy, 53:8392.

Lopez, M.V., \& Satti, S.M.E. (1996). Calcium and potassium-enhanced growth and yield of tomato under sodium chloride stress. Plant Science, 114:1927.

Maas, E.V., \& Grattan, S.R. (1999). Crop Yields as Affected by Salinity. pp: 55-108. In: Agricultural Drainage. Chapter: Crop Yields as Affected by Salinity. Publisher: American Society of Agronomy. Editors: R. W. Skaggs and J. van Schilfgaarde.

Mandal, K.G., Saha, K.P., Gosh, P.L., Hati, K.M. \& Bandyopadhyay, K.K. (2002). Bioenergy and economic analyses of soybean based crop production systems in central India. Biomass \& Bioenergy, 23:337-345.

Mihov, M., \& Antonova, G. (2009). Energy assessment of monoculture and intercropping growing systems of broccoli. Proceedings of International Conference "Soil tillage and ecology", 1-5 September 2009, Albena/ Bulgaria, p: 190-195.

Mihov, M., \& Tringovska, I. (2010). Energy efficiency improvement of greenhouse tomato production by applying new biofertilizers. Bulgarian Journal of Agricultural Science, 16:454-458.

Mirasi, A., Samadi, M., \& Rabiee, A.H. (2015). An analytical method to survey the energy input-output and emissions of greenhouse gases from wheat and tomato farms in Iran. Biological Forum, 7:52-58.

Mohammadi, A., \& Omid, M. (2010). Economical analysis and relation between energy inputs and yield of greenhouse cucumber production in Iran. Applied Energy, 87:191-196.

Mohammadi, A., Tabatabaeefar, A., Shahin, S., Rafiee, S., \& Keyhani, A. (2008). Energy use and economical analysis of potato production in Iran a case study: Ardabil province. Energy Conversion and Management, 49:3566-3570.

Monjezi, N., Sheikhdavoodi, M.J., \& Taki, M. (2011). Energy use pattern and optimization of energy consumption for greenhouse cucumber production in Iran using data envelopment analysis (DEA). Modern Applied Science, 5:139-151.

Özkan, B., Kürklü, A., \& Akçaöz, H. (2004). An inputoutput energy analysis in greenhouse vegetable production: a case study for Antalya region of Turkey. Biomass Bioenergy, 26:189-195.

Pahlavan, R., Omid, M., \& Akram, A. (2011). Modeling and sensivity analysis of energy inputs for greenhouse cucumber production. Journal of Agricultural Technology, 7:1509-1521.

Pahlavan, R., Omid, M., \& Akram, A. (2012). The relationship between energy inputs and crop yield in greenhouse basil production. Journal of Agricultural Science and Technology, 14:1243-1253.

Pascale, S., Angelino, G., Graziani, G., Maggio, A., \& Pascale, S. (2003). Effect of salt stress on water relations and antioxidant activity in tomato, ActaHorticulturae, 613:39-46.

Pashaee, F., Rahmati, M.H., \& Pashaee, P. (2008). Study and determination of energy consumption to produce tomato in the greenhouse. The $5^{\text {th }}$ National Conference on Agricultural Machinery Engineering and Mechanization, 27-28 August 2008, Mashhad/Iran.

Rafiee, S., Seyed, H., Mousavi, A., \& Ali, M. (2010). Modeling and sensivity analysis of energy inputs for apple production in Iran. Energy, 35:3301-3306.

Razavinia, B., Fallah, H., \& Niknejad, Y. (2015). Energy efficiency and economic analysis of winter caltivation (lettuce, bersim clover, broad bean) in Mazandaran province of Iran. Biological Forum, 7:1452-1460.

Restuccia, G., Marchese, M., Mauromicale, G., Restuccia, A., \& Battaglia M. (2002). Yield and fruit quality of tomato grown in greenhouse with saline irrigation water. ActaHorticulturae, 614:699-704.

Rezvani Moghaddam, P., Feizi, H., \& Mondani, F. (2011). Evaluation of tomato production systems in terms of energy use efficiency and economical analysis in Iran. Notulae Scientia Biologicae, 3(4): 58-65.

Sabaghi, M.A., \& Masihi, S. (2014). Examination of relationship between energy of consumption inputs and performance of tomato crops in cultivation under plastic in Dezful city. Indian Journal of Fundamental and Applied Life Sciences, 4:383-389.

Sami, M., \& Reyhani, H. (2015). Environmental assessment of cucumber farming using energy and greenhouse gas emission indexes. IIOAB Journal, 6:15-21

Sepat, N.K., Sepat, S.R., Sepat, S., \& Kumar, A. (2013).Energy use efficiency and cost analysis of tomato under greenhouse and open field production system at Nubra valley of Jammu and Kashmir. International Journal of Environmental Sciences, 3:1233-1241.

Sevgican, A., Tüzel, Y., Gül, A., \& Eltez, R.Z. (1990). Türkiye'de örtü altı yetiştiriciliği. V. Türkiye Ziraat Mühendisleri Teknik Kongresi, 17-21 Ocak 1990, Ankara, s: 679-707 (in Turkish).

Shamsabadi, H., Abedi, M., Ahmad, D., \& Taheri-Rad, A. (2017). Comparison of energy consumption and greenhouse gas emission footprint caused by agricultural products in greenhouses and open fields in Iran. Energy Equipment and Systems, 5:157-163.

Singh, J.M. (2002). On farm energy use pattern in different cropping systems in Haryana, India. MSc Thesis, International Institute of Management University of Flensburg. Sustainable Energy Systems and Management, Germany.

Taki, M., Ajabshirchi, Y., Mobtaker, H.G., \& Abdi, R. (2012). Energy consumption, input-output relationship and cost analysis for greenhouse productions in Esfahan province of Iran. American Journal of Experimental Agriculture, 2:485-501.

Taki, M., Abdi, R., Akbarpour, M., \& Mobtaker, H.G. (2013). Energy inputs-yield relationship and sensivity analysis for tomato greenhouse production in Iran. CIGR Journal, 15:59-67.

Tülücü, K. (2003). Özel Bitkilerin Sulanması. Çukurova Üniversitesi Ziraat Fakültesi Tarımsal Yapılar ve Sulama Bölümü. Genel Yayın No: 254, Adana (in Turkish).

UI, M.A. (2007). Su kullanım bilinci ve organik tarım. Bahçeşehir Üniversitesi Organik Tarım Kongresi, 1920 Ekim 2007, İstanbul/Türkiye, s:113-125 (in Turkish).

Yaldız, O., Öztürk, H.H., Zeren, Y., \& Başçetinçelik, A. (1993). Energy usage in production of field crops in Turkey. $5^{\text {th }}$ International Congress on Mechanization 
and Energy in Agriculture. 11-14 October 1993, Kuşadası/Turkey, p: 527-536 (in Turkish).

Yaylalı, İ.K. (2007). Değişik tuz konsantrasyonuna sahip farklı sulama suyu uygulamalarının domateste verim ve kalite üzerine etkileri. Doktora Tezi, Selçuk Üniversitesi, Konya (in Turkish).

Yelmen, B., Şahin, H.H., \& Çakır, M.T. (2019). Energy efficiency and economic analysis in tomato production: A case study of Mersın province in the Mediterranean region. Applied Ecology and
Environmental Research, 17:7371-7379.

Yılmaz, İ., Özalp, A., \& Aydoğmuş, F. (2010). Antalya ili bodur elma üretiminde enerji kullanım etkinliğinin belirlenmesi: Elmalı ilçesi örneği. Akdeniz Üniversitesi Ziraat Fakültesi Dergisi, 23:93-97 (in Turkish).

Yousefi, M., Darijani, F., \& Jahangiri, A.A. (2012). Comparing energy flow of greenhouse and open-field cucumber production systems in Iran. African Journal of Agricultural Research, 7:624-628. 